\title{
Покрытия из массивов субмикронных частиц Ge и их антиотражающие свойства
}

\author{
А.А. Шкляев ${ }^{1,2)}$, А.В. Царёв ${ }^{1,2)}$, Е.А. Колосовский ${ }^{1)}$, К.В. Аникин ${ }^{1)}$, А.Г. Милёхин ${ }^{1,2)}$ \\ ${ }^{1}$ Институт физики полупроводников им. А.В.Ржанова СО РАН, \\ Новосибирск, 630090, пр. Ак. Лаврентьева, 13 \\ ${ }^{2}$ Новосибирский государственный университет, Новосибирск, 630090, ул. Пирогода, 2 \\ тел:+7 (913)001-00-85, эл.почта: shklyaev@isp.nsc.ru
}

DOI 10.34077/RCSP2019-30

Диэлектрические частицы на поверхностях твёрдых тел являются эффективным инструментом для манипуляций с падающим светом, когда его длина волны $\lambda$ и размер частиц $d$ удовлетворяют соотношению $\lambda \sim \mathrm{nd}$, где $\mathrm{n}$ - показатель преломления. При таких условиях в частицах возникают электрические и магнитные резонансы. В зависимости от формы частиц они также могут приводить к перераспределению интенсивности рассеянного света за счёт фокусировки. Один из наиболее простых и эффективных способов получения массивов частиц основан на использовании такого явления, как несмачиваемость. Осаждение $\mathrm{Ge}$ на поверхности $\mathrm{SiO}_{2}$ приводит к образованию частиц $\mathrm{Ge}$ без образования смачивающего слоя, как это было впервые отмечено в [1]. В предшествующих многочисленных работ проводилось осаждение сравнительно малых количеств $\mathrm{Ge}$ (слои номинальной толщины до 10 нм) для получения частиц $\mathrm{Ge}$ нанометрового размера с целью изучения квантово-размерных эффектов. В данной работе нами исследовался процесс образования частиц Ge субмикронного размера на $\mathrm{SiO}_{2}$ при осаждении покрытий $\mathrm{Ge}$ толщиной до 100 нм. B качестве подложек использовались пластины $\mathrm{Si}(100)$, покрытые как сверхтонкой плёнкой $\mathrm{SiO}_{2}$, так и плёнкой толщиной около 1 мкм. Эксперименты по получению частиц Ge проводились следующим образом. Сначала осаждался сплошной слой $\mathrm{Ge}$ на $\mathrm{SiO}_{2}$ при комнатной температуре подложки. Последующий отжиг выращенных структур проводился в вакуумной печи при температуре в диапазоне от 550 до $900{ }^{\circ} \mathrm{C}$. Было обнаружено, что механизм образования частиц Ge при реализации несмачиваемости зависит от толщины слоя Ge и температуры отжига (см. Рис.).
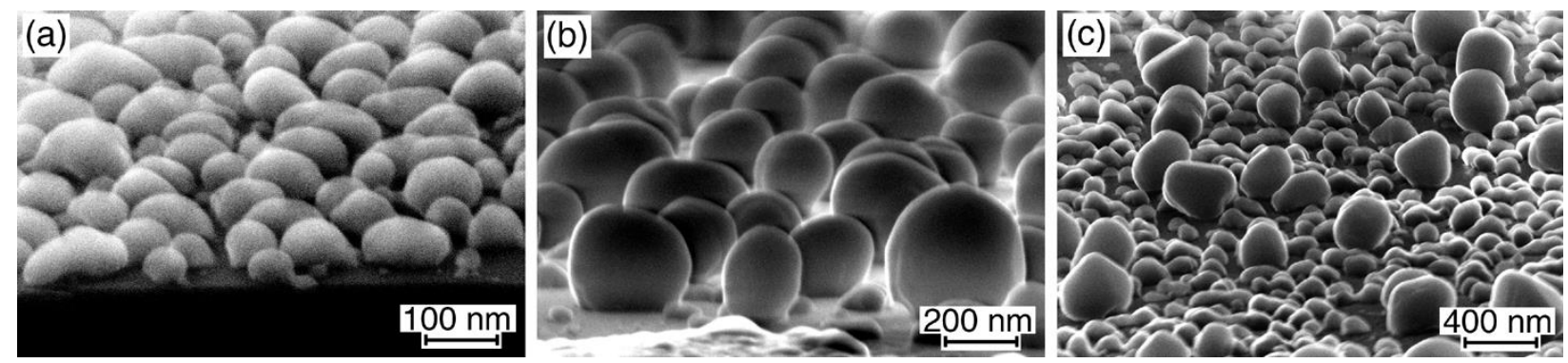

Рисунок. Изображения в сканирующем электронном микроскопе частиц $\mathrm{Ge}$ на поверхности $\mathrm{SiO}_{2}$, полученных отжигом сплошного слоя Ge толщиной (a) 40, (b) 60 и (c) 86 нм при температурах 700, 800 и $850^{\circ} \mathrm{C}$ соответственно.

Полученные структуры использовались для измерения спектров отражения света. Проводились расчёты спектров отражения методом 3D FDTD. Путём сравнения экспериментальных и рассчитанных спектров определялся вклад массивов частиц $\mathrm{Ge}$ в отражение света. В результате были получены данные для определения возможности использования массивов частиц $\mathrm{Ge}$ в качестве антиотражающих покрытий.

Работа проводилась при финансовой поддержке РФФИ, грант № 18-29-20066.

\section{Лumepamypa}

[1] A.A. Shklyaev, M. Ichikawa. Effect of interfaces on quantum confinement in $\mathrm{Ge}$ dots grown on $\mathrm{Si}$ surfaces with a $\mathrm{SiO}_{2}$ coverage. Surf. Sci. 2002. v. 514, pp. 19-26. 